\title{
CORPORATE SOCIAL RESPONSIBILITY (CSR) DALAM PRESPEKTIF HUKUM ISLAM
}

Oleh:

\section{Jejen Hendar}

\author{
Fakultas Hukum Universitas Islam Bandung \\ encep.jejen@gamail.com
}

\begin{abstract}
ABSTRAK
Isu terkait Tanggung Jawab Sosial Perusahaan (CSR), merupakan hal yang tidak asing lagi dalm dunia hukum dan perusahaan, ketika CSR ini dihubungkan dengan hukum islam, apakah sebenarnya islam telah mengatur mengenai hal ini? Sehingga kegiatan yang dilakukan oleh perusahan tersebut bernilai ibadah bagi para pelaku usaha. Disamping itu kegiatan CSR ini merupakan suatu kegiatan yang dilakukan yang bersifat kemanusiaan. Sedangkan maslahah mursalah ini merupakan suatu hukum dimana tidak terdapat dail mengenai perintah dan larangannya.CSR sendiri merupakan suatu komitmen Perseroan untuk berperan serta dalam pembangunan ekonomi berkelanjutan guna meningkatkan kualitas kehidupan dan lingkungan yang bermanfaat, baik bagi Perseroan sendiri, komunitas setempat, maupun masyarakat pada umumnya. Sedangkan maslahah mursalah sendiri memiliki definisi yaitu suatu kemaslahatan yang tidak dibahas oleh syara' dan tidak pula terdapat dalil-dalil yang menyuruh untuk mengerjakan atau meninggalkannya, sedangkan jika dikerjakan akan mendatangkan kebaikan yang besar atau kemaslahatan.
\end{abstract}

Kata Kunci: tanggung jawab sosial perusahaan, maslahah mursalah, hukum islam

\section{ABSTRACT}

Issues related to Corporate Social Responsibility (CSR), it is no stranger to the world of law and the company's preformance, when CSR is associated with Islamic law, if in fact Islam has been set in this regard? So that the activities undertaken by these companies is worth worship for businesses. Besides, CSR is an activity undertaken humanitarian nature. Maslahah mursalah While this is a law where there is no dail about the commands and prohibitions. CSR itself is a commitment of the Company to participate in the sustainable economic development to improve the quality of life and environment benefits the Company itself, the local community and society in general. While maslahah mursalah itself has a definition that is a benefit that is not covered by the Personality 'and nor are the arguments sent to work or leave it, whereas if done will bring great good or benefit.

Keywords: corporate social responsibility, maslahah mursalah, islamic law

\section{A. Pendahuluan}

\section{Latar Belakang}

Dalam islam tidak ada tepat bagi orang yang kikir. Jangankan bagi orang kaya dan hidup berkecukupan, terhadap orang dalam konteks hidup hanya cukup untuk makan saja berprilaku saling berbagi sangat dianjurkan. Dalam surat Al-Imran ditegaskan bahwa surga disediakan bagi orang-orang yang menafkahkan hartanya dalam keadaan lapang maupun sempit, yang berbunyi: ${ }^{1}$

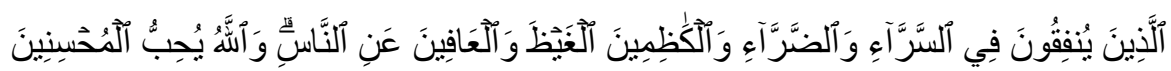

\footnotetext{
${ }^{1}$ Depatemen Agama. Al-Qur'an dan Terjemahan. (Jakarta. Depag: 2011)
}

40 CORPORATE SOCIAL RESPONSIBILITY (CSR) DALAM PRESFEKTIF HUKUM ISLAM 
Artinya:

"Orang-orang yang menafkahkan (hartanya), baik di waktu lapang maupun sempit, dan orang-orang yang menahan amarahnya dan mema'afkan (kesalahan) orang. Allah menyukai orang-orang yang berbuat kebajikan." (QS. Al-Imran: 134)

Dengan kata lain berderma bukan kaitan dengan keadaan kaya saja akan tetapi sekalipun seseorang berada dalam keadaan kondisi pas-pasan bahkan miskin, berderma adalah sebuah keharusan. Maka dalam konteks perusahaan, ketika meraup laba besar maupun sedang sulit karena diterpa krisis, bukan merupakan suatu halangan untuk melakukan Corporate Social Responsibility (CSR).

Dalam konteks perusahaan, tidak diperkenankan para CEO dengan hanya menggunakan keuntungannya saja tanpa beramal melalui CSR. CSR sejatinya merupakan mekanisme sosial untuk mendistribusikan harta yang dititipkan oleh Allah SWT kepada yang lebih berhak menerimanya. ${ }^{2}$

Ketika CSR ini dihubungkan dengan hukum islam, apakah sebenarnya islam telah mengatur mengenai hal ini? Sehingga kegiatan yang dilakukan oleh perusahan tersebut bernilai ibadah bagi para pelaku usaha. Disamping itu kegiatan CSR ini merupakan suatu kegiatan yang dilakukan yang bersifat kemanusiaan. Sedangkan maslahah mursalah ini merupakan suatu hukum dimana tidak terdapat dalil mengenai perintah dan larangannya.

Sedangkan CSR ini didefinisikan sebagai suatu komitmen perusahaan kepada masyarakat. Maka dalam hal ini bagai mana pandangan islam terhadap kegiatan yang dilakukan oleh perusahaan dalam hal ini yakni kegiatan CSR. Selain itu bagaimana pandangan filsafat hukum islam terhadap pelaksanaan CSR ini? Sehingga hal ini lah yang mendorong penulis untuk menulis paper ini terhadap pelaksanaan yang dilakukan oleh perusahaan ditinjau dari Maslahah Mursalah.

\section{Rumusan Masalah}

Berdasarkan latar belakang tersebut diatas, maka rumusan maslah yang dikaji dalam paper ini ialah sebagai berikut:

a. Bagaimana Corporate social responsibility (CSR) dalam hukum Islam?

b. Bagaimana implementasi Corporate social responsibility (CSR) di tinjau dari Maslahah Mursalah?

\section{B. Pembahasan}

\section{Corporate Social Responsibility (CSR) Ditinjau dari Hukum Islam}

Corporate social responsibility (CSR) atau sering dikenal dengan sebutan Tanggung Jawab Sosial Perusahaan, didefinisikan sebagia berikut; dalam ketentuan peraturan perundang-undangan sebagi mana termuat dalam Pasal 1 angka 3 yang berbunyi: ${ }^{3}$

"Tanggung Jawab Sosial dan Lingkungan adalah komitmen Perseroan untuk berperan serta dalam pembangunan ekonomi berkelanjutan guna meningkatkan kualitas kehidupan dan lingkungan yang bermanfaat, baik bagi Perseroan sendiri, komunitas setempat, maupun masyarakat pada umumnya."

Menurut peraturan perundang-undangan tersebut diatas dijelsakan bahwasannya CSR merupakan suatu komitmen yang dilakukan oleh sebuah perusahaan terhadap masyarakat sekitar. Komitmen tersebut diwujudkan dalam bentuk peran serta sebuah perusahaan sebagai bentuk dari perekonomian nasional yang diselenggarakan berdasar atas

\footnotetext{
2 Joko Prastowo dan Miftahul huda, Corporate Social Responsibility Kunci Meraih Kemuliaan Bisnis. (Samudra Biru. Yogyakarta: 2011), hlm. 74.

${ }^{3}$ Undang-Undang Nomor 40 Tahun 2007 tentang Perseroan Terbatas
} 
demokrasi ekonomi dengan prinsip kebersamaan, efisiensi berkeadilan, berkelanjutan, berwawasan lingkungan, kemandirian, serta dengan menjaga keseimbangan kemajuan dan kesatuan ekonomi nasional, perlu didukung oleh kelembagaan perekonomian yang kokoh dalam rangka mewujudkan kesejahteraan masyarakat. ${ }^{4}$ Sehingga perusahaan tersebut dapat melaksanakan kegiatan usahanya dengan memperhatikan serta membantu dalam mensejahterakan masyarakat indonesia.

Ketika melihat dalam pandangan filsafat hukum islam memberikan komitmen perusahaan kepada masyarakat sering dikenal dengan zakat. Dalam hal zakat ini merupakan salah satu ciri dari agama islam, dimana agama islam memiliki sifat kemanusian, sehingga zakat diwajibkan kepada orang kaya yang hartanya nisab. Selain itu zakat diperuntukan kepada orang-orang yang membutuhkan, baik yang disebut fakir miskin. ${ }^{5}$ Disamping itu dalam Al-Qur'an dijelaskan mengenaki kewajiban untuk saling tolong menolong, yakni dalam Surat Al-Maidah ayat $2:^{6}$

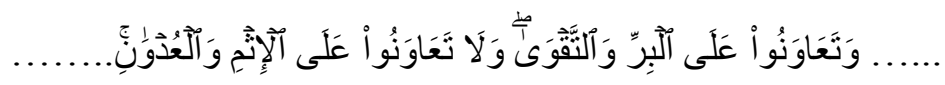

Artinya:

“........ dan tolong-menolonglah kamu dalam (mengerjakan) kebajikan dan takwa, dan jangan tolong-menolong dalam berbuat dosa dan pelanggaran. .....”. (QS. Al-Maidah: 2)

Dalam al-qur'an dengan jelas dikatakan bahwasannya bagi umat isam dalam melaksanakan tolong menolong tersebut merupakan suatu kewajiban dan keharusan. Disamping itu islam juga mewajibkan membayar zakat. Perintah melaksanakan zakat tersebut sangat banyak dikarenakan pentignya fungsi zakat, antara lain dalam surat AtTaubah : 103, yang berbunyi:

Artinya:

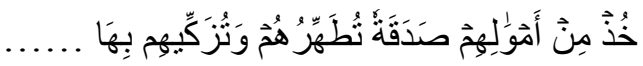

Ambillah zakat dari sebagian harta mereka, dengan zakat itu kamu membersihkan dan mensucikan (Q.S. At- Taubah : 103)

Perintah mengenai zakat ini masih banyak lagi, zakat ini mengandung hikmah yang begitu besar serta bersifat rohaniah dan pilosofis. Hikmah tersebut digambarkan dalam berbagai ayat dalam Al-Qur'an dan Hadits, diantaranya ialah: ${ }^{7}$

a. Mensyukuri karunia ilahi, menumbuh suuburkan harta dan pahala serta membersihkan diri dari sifat-sifat kikir, dengki, iri serta dosa.

b. Melindungi masyarakat dari bahaya kemiskinan dan akibat kemelaratan

c. Mewujudkan rasa soidaritas dan kasih sayang antara sesama manusia,

d. Manifestasi kegotongroyongan dan tolong-menolong dalam kebaikan dan taqwa,

e. Mengurangi kefakir-miskinan yang merupakan masalah sosial,

f. Membina dan mengebangkan stabilitas sosial,

g. Salah satu jalam ewujudkan keadilan.

Melihat hikmah yang ditimbulakan akibat pelaksanaan zakat ini, penulis mencoba menarik suatu garis keterkaitan antara Tanggung Jawab Sosial Perusahaan dengan zakat, zakat disini yang diatur oleh Islam ialah zakat perusahaan/zakat pendapatan/zakat

\footnotetext{
${ }^{4}$ Konsideran Menimbang UU PT

${ }^{5}$ Ismail Muhammad Syah, dkk. Filsafat Hukum Islam, (Bumi Aksara. Jakarta: 1999), hlm. 118

${ }^{6}$ Depatemen Agama. Al-Qur'an dan Terjemahan.......

${ }^{7}$ Mohammad Daud Ali, Sistem Ekonomi Islam Zakat dan Wakaf, (UI Press. Jakarta: 1988), hlm. 41.
} 
perdagangan, seperti yang dituliskan oleh Mohammad Daud Ali dalam bukunya, ${ }^{8}$ yang menuliskan mengenai zakat. Zakat perindustrian seperti terkstil, baja, keramik, batu merah, genting, kapur, batik, dan ukiran-ukiran. Dengan nisab harta tersebut sejumlah ataupun senilai dengan 96 gram emas murni, dengan haul selama 1 tahun, maka kadar zakat yang dikeluarkan adalah $2 \frac{1}{2} \%$. Sedangkan untuk perindustrian dibidang pariwisata seperti hotel, cottage, penginapan, villa, restoran, bioskop dan kolam renang dengan nisab hartanya adalah senilali 96 gram emas murni dan masa haulnya selama 1 tahun dengan kadar zakat sebanyak $2 \frac{1}{2} \%$.

Ketika dikaitkan dalam zakat sebuah perusahaan maka dalma hal ini Al-Qur'an telah memerintahkan pula, Ibnu al Mundzir mengatakan bahwasannya para ahli ilmu sepakat bahwa dalam baran-barang yang dimaksudkan sebagai barang-barang dagangan, zakatnya dikelurakan ketika telah mencapai $h a w l .^{9}$ Adapun dalil tentang zakat perdaganan ialah:

Artinya:

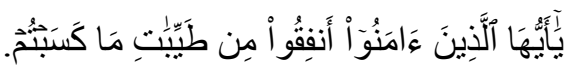

Hai orang-orang yang beriman, nafkahkanlah (di jalan Allah) sebagian dari hasil usahamu yang baik-baik ...... (Q.S. Al-Baqarah: 167)

Selain itu mengenai zakat sebuah perusahaan dibagi menjadi kedalam dua kategori, yakni; ${ }^{10}$ (1) perusahaan yang hanya menggunakan alat-alat sederhana dan yang meodal utamanya untuk membeli bahan-bahan pokok, membayar upah karyawan dan ongkosongkos. Dan (2) perusahaan yang modal utamanya untuk alat-alat canggih yang amat mahal harganaya.

Untuk jenis perusahaan pertama cara penghitungan zakatnya yakni menghitung saldo uang di kas dan simpanan di bank pada akhir tahun, ditambah persediaan bahanbahan dan barang jadi serta piutang yang lancar. Kemudian jumlah semua itu dikurangi beban hutang yang harus dibayar lalu dikeluarkan zakatnya sebanyak $2 \frac{1}{2} \%$ dari total jumlah aset yang tersisa.

Sedangkan untuk jenis perusahaan yang kedua zakat yang dikeluarkan dengan cara penghitungannya yakni tidak dihitung dari harga mesin-mesin tersebut, tetapi dari hasil prosuksinya dan mengeluarkan zakatnya sebesar $10 \%$. Perbedaan terebut dikarenakan jika yang pertama menggunakan seluruh modalnya untuk diputarkan sehingga dianggap sebagai harta yang tumbuh dan berkembang, jika yang kedua sebagian besar dari modalnya digunakan untuk membeli alat-alat mahal sehingga tidak dianggap sebagai harta yang tumbuh dan berkembang melainkan dihitung dan dikeluarkan hanya dari hasil laba yang diperoleh saja. ${ }^{11}$

Malihat hal tersebut diatas hukum islam telah lama nengatur mengenai tanggung jawab sebuah perusahaan, namun dalam hal ini digambarkan atau dibentuk melalui zakat. Ternyata hubungan antara zakat dan kepedulian atau tanggung jawab perusahaan tersebut merupakan suatu hal yang saling keterkaitan, dan dapat dikatakan memiliki makna yang sama. Ketika berbicara mengenai perindustrian ialah islam pun dalam melakukan

\footnotetext{
${ }^{8}$ Ibid... hlm. 58.

${ }^{9}$ Wahbah Al-Zuhayly, Zakat Kajian Berbagai Mazhab, (Remaja Rosdakarya. Bandung: 2008), hlm. 169170.

${ }^{10}$ Muhammad Bagir Al-Habsyi, Fiqih Praktis Menurut Al-Qur'an, Asunnah, Pendapat Para Ulama, (Mizan. Bandung: 1999), hlm 298.

${ }^{11}$ Ibid ... hlm 299.
} 
prekonomian memiliki konsep dasar ekonomi islam, ada tiga pilar pokok dalam ajaran islam yakni sebagai berikut: ${ }^{12}$

a. Aqidah, komponen ajaran islam yang mengatur keyakinan atas keberadaan dan kekuasaan Allah, sehingga harus menjadi keimanan seorang muslim manakala melakukan berbagai aktivitas di muka bumi semata-mata untuk mendapat ridha Allah.

b. Syari'ah, komponen ajaran islam yang mengatur tentang kehidupan seorang muslim baik dalma bidang ibadah maupun dalam bidang muamalah yang merupakan aktualisasi aqidah yang menjadi keyakinannya.

c. Akhlaq, landasanprilaku dankepribadian yang akan mencirikan dirinya sebagai seorang muslim yang taat berdasarkan syari'at dan aqidah yang menjadi pedoman hidupnya sehingga disebut memiliki akhlaqul karimah

Ketika berbicara mengenai konsep, maka negara indosesia mempunyai konsep dalam mewujudkan masyarakat yang sejahtera yakni sebagai mana tertuang dalam pembukan undang-Undang Dasar Negara Republik Indonesia khususnya pada alinea ke empat yang berbunmyi:

“....yang melindungi segenap bangsa Indonesia dan seluruh tumpah darah Indonesia dan untuk memajukan kesejahteraan umum,...."

Dalam alinea tersebut dengan jelas bahwasannya negara ini melindungi setiap masyarakat dan seruruh elemen m,asyarakat dari sabang sampai merauke. Disamping itu dengan jelas mengungkapkan bahawasannya negara berperan penting dalam mewujudkan kesejahteraraan di masyarakat tersebut yakni salah satunya dengan memberikan kesejahteraan dibidang ekonomi. Dasar yang digunakan yakni tertuang dalam pasal 33 ayat (4) UUD Negara Republik Indonesia tahun 1945 yang ber bunyi: ${ }^{13}$

"Perekonomian nasional diselenggarakan berdasar atas demokrasi ekonomi dengan prinsip kebersamaan, efisiensi berkeadilan, berkelanjutan, berwawasan lingkungan, kemandirian, serta dengan menjaga keseimbangan kemajuan dan kesatuan ekonomi nasional."

Pada ayat tersebut dijelaskan mengenai perekonomian nasionalyang diselenggarakan dengan prinsip kebersamaan yang mana dalam hal ini sesuai dengan apa yang difirmankan oleh Allah AWT dalam QS. Al-Maidah: 2 mengenai tolong menolong, maka dalam kontek perusahaan ini ilah dengan melakukan kegitan CSR ini. Selain itu pada ayat tersebut juga dikatakan bahwasannya dengan menggunakan prinsip yang berwawasan lingkungan, sebinhha dalam konteks CSR ini dapat memperhatikan lingkungan sekitar. Maka dalam konteks filsafat ini adanya CSR ini mempunyai cita yang sangat bagus yakni memberikan atau menciptakan suatu hal yang berpedoman kepada keadilan, baik keadilan yang bersifat soskial maupun keadilan yang besifat lingkungan.

Kegiatan CSR ini ketika dipandang dari segi etika bisnis, dalam hal ini Syed Nawab Heidar Naqwi menguraikan prinsip-prinsip ekonomi islam yang meliputi: ${ }^{14}$

a. Tauhid, dalam hal ini tauhid merupakan filsafat ekonomi islam yang menjadi orientasi dasar dari ilmu ekonomi, yang paradigmanya relevan dengan nilai logik, etik dan estetik yang dapat difungsionalisasikan ke tengah tingkah laku ekonomi manusia. Selain itu tauhid juga dalam ekonomi mengantarkan para pelaku ekonomi untuk berkeyakinan bahwa harta benda adalah milik Allah semata.

\footnotetext{
${ }^{12}$ Amir Mahmud, Bank Syari'ah Teori, Kebijakan dan Studi Empiris di Indonesia, (Erlangga. Jakarta: 2010), hlm. 24.

${ }^{13}$ Pasal 33 ayat (4) UUD Negara Republik Indonesia 1945

${ }^{14}$ Muhammad, Aspek Hukum dalam Mu'amalat, (Graha Ilmu. Yogyakarta: 2007), hlm. 82-83.
}

44 CORPORATE SOCIAL RESPONSIBILITY (CSR) DALAM PRESFEKTIF HUKUM ISLAM 
b. Keseimbangan, hal ini dalam ekonomi memili kekuatan untuk membentuk mozaik pemikiran seseorang bahwa sikap keseimbangan dapat mengantarkan manusia kepada keadaan keharusan adanya fungsi sosial bagi harta benda, artinya praktek monopoli pemusatan kekuatan ekonomi, penguasaan pangsa pasar dan sebagainya harus dihindari.

c. Kehendak bebas, hal ini merupakan prinsip yang mengantarkan manusia menyakini bahwa Allah tidak hanya memiliki kebebasan mutlak, tetapi Dia juga dengan sifat Rahman dan Rahim-Nya menganugrahkan kepada manusia kebebasan untuk memilih.

Tiga prinsip yang dikemukan oleh Syed Nawab ini penulis melihat bahwasannya kesemuanya tersebut merupakan suatu landasan dalam melakukan perkonomian yang memiliki pondasi terhadap kepedulian sesama. Yakni kepedulian terhadap lingkungan dan sosial. Dalam konteks kegiatan CSR ini tidak terlepas dari prinsip sosial dan lingkungan. Sehingga dapat dikategorikan mempunyai etika bisnis yang arif. Etika bisnis ini tidak terlepas dari suatu nilai keadilan, diantaranga adalah keadilan distribusi islam, dalam hal ini menurut Munawar Iqbal, bahwa yang dimaksud dengan distributive justice dalam islam ialah tercermin dalam tiga hal berikut: ${ }^{15}$

a. Jaminan terpenuhinya kebutuhan dasar bagi semua.

b. Objektivitas atau keadilan tetapi bukan persamaan dalam pendapatan individu.

c. Pembatasan ketidak merataan ekstreem dalam pendapatan kekayaan individu.

Selain itu islam membangun kohesivitas sosial, kasih sayang dan persaudaraan. Hal tersebut diwujudkan dalam kewajiban zakat, infaq, dan sedekah yang merupakan bentuk riil dari kepedulian antar sesama yang dibangun guna membangun keharmonisan sosial. Sehingga dapat disimpulkan bahwa perbuatan atau keputusan etis tergantung niatnya, yang dalam sebuah hadits rasulullah saw bersabda, yang artinya: ${ }^{16}$

"Bahwasannya semua amal itu tergantung niatnya, dan bahwasannya apa yang diperoleh oleh seseorang adalah sesuai dengan apa yang diniatkannya (HR. Bukhari)"

Sehingga kegiatan yang dilakukan oleh sebuah perusahaan yakni kegiatan tanggung jawab sosial perusahaan, mengenai dampak ataupun akibat yang ditimbulkan jika mengacu kepada hadits tersebut diatas ialah tergantung kepada niat dari para pelaku usaha itu sendiri.

Basis pelaksanaan CSR jika merujuk ajaran islam pada intinya ialah kekayaan tersebut tidak boleh menumpuk pada satu kelompok orang tertentu saja. ${ }^{17}$ Sebab islam sangat mengutuk prilaku mengumpulkan harta benda tanpa mempedulikan orang lain. Sehingga dalam hal ini Allah SWT memperingatkan kepada orang tersebut dalam AlQur'an Surat Al-Humazah: ${ }^{18}$

Artinya:

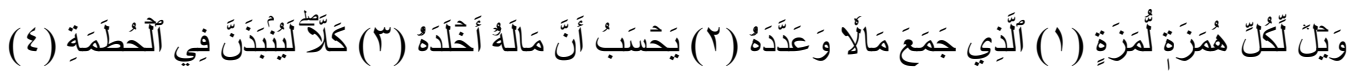

Kecelakaanlah bagi Setiap pengumpat lagi pencela (1), yang mengumpulkan harta dan menghitung-hitung* (2), Dia mengira bahwa hartanya itu dapat mengkekalkannya (3), sekali-kali tidak! Sesungguhnya Dia benar-benar akan dilemparkan ke dalam Huthamah (4). (Q.S. Al-Humazah : 1-4)

\footnotetext{
${ }^{15}$ Faisal Badroen, dkk, Etika bisnis dalam Islam, (Kencana Prenada Media. Jakarta: 2006), hlm. 49.

${ }^{16}$ Ibid... hlm. 50

${ }^{17}$ Joko Prastowo dan Miftahul Huda, Corporate Social.. Op.Cit........ hlm. 72-73.

${ }^{18}$ Depatemen Agama. Al-Qur'an.... op cit....
} 
*Maksudnya mengumpulkan dan menghitung-hitung harta yang karenanya dia menjadi kikir dan tidak mau menafkahkannya di jalan Allah.

Dalam konteks perusahaan, dengan demikian tidak diperkenankan kepada para CEO dengan hanya menggunakan keuntungannya tanpa beramal melalui CSR. CSR sejatinya merupakan mekanisme sosial untuk mendistribusikan harta yang dititipkan oleh Allah SWT kepada yang lebih berhak menerimanya. Pada sisilain CSR juga dapat dikatakan wajib ketika dikaitkan dengan Zakat perusahaan, akan tetapi harus memenuhi kepada beberapa syarat yang harus dipenuhi. Sebagai mana telah dijelsakan sebelumnya mengenai zakat sebuah perusahaan.

\section{Implementasi Corporate Social Responsibility (CSR) dalam Prosfektif Maslahah Mursalah.}

Corporate Social Responsibility telah banyak dilakukan oleh kangan perusahaan. Baik perusahan yang bergerak dibidang jasa, konsumsi ataupun yang lainnya. Jika dipahami mengenai manfaat dari pelaksanaan CSR ini seperti yang diungkapakan oleh Wicipto dalam jurnal hukum, menyatakan beberapa manfaat CSR bagi perusahaan, antara lain;
a. Mempertahankan dan mendonkrak reputasi serta citra perusahaan
b. Mendapatkan lisensi untuk beroperasi secara sosial
c. Mengurangi atau memperkecil risiko perusahaan
d. Melebarkan akses sumberdaya bagi operasional usaha
e. Membuka peluang pasar yang lebih luas
f. Mereduksi biaya perusahaan
g. Memperbaiki hubungan dengan pemangku kepentingan (stakeholders)
h. Memperbaiki hubungan dengan regulator
i. Meningkatkan semangat dan produktivitas karyawan
j. Peluang untuk mendapatkan penghargaan.

Sedangkan dalam praktiknya, faktor yang sangat berpengaruh terhadap implementasinya CSR ini ialah bagaimana komitmen pimpinan perusahaan tersebut. Apabila komitmen pimpinan tinggi terhadap implementasi CSR, maka CSR akan berjalan dengan baik dan begitu juga sebaliknya. Pemimpin yang berkomitmen tinggi atas implementasi CSR, CSR biasanya dintegrasikan dalam perumusan jangka panjang perusahaan, karena CSR diyakini akan memberikan manfaat jangka panjang, baik perusahaan maupun para pemangku kepentingan.

Selain itu perusahaan juga tanpa adanya penerapan Good Corporate Governance yang efektif, perusahaan akan sulit untuk bisa memperkuat posisi, memperluas jaringan, dan menunjukan kinerjanya dengan lebih efektif. ${ }^{19}$ Sehingga solidaritas sosial, penegakan nilai-nilai moral dan hukum akan berjalan efektif. ${ }^{20}$

Ketika kegiatan usaha yang dilakukan oleh seseorang dikaitkan dengan kaidah atau hukum-hukum islam, dalam hal ini ketika kegiatan CSR ini dikaitkan dalam hukum islam dan hukum negara (hukum positif), maka dampak yang ditimbulkanpun akan berbeda, jika kegiatan tersebut tanpa menggunakan dasar dari kedua sumber hukum tersebut.

Dalam hukum positif telah jelsa pengaturan mengenai CSR ini baik dalam UndangUndang Nomor 40 Tahun 2007 tentang Perseroan Terbatas yang kemudian diperjelas lagi dengan Peraturan Pemerintah Nomor 47 Tahun 2012 tentang Tanggung Jawab Sosial dan

\footnotetext{
19 M. Umer Capra dan Habib Ahmed, diterjemahkan oleh Ikhwan Abidin Asri, Corporate governance Lembaga Keuangan Syari'ah, (Bumi Aksara. Jakarta: 2008), hlm 13.

${ }^{20}$ Ibid.... hlm. 36.
} 
Lingkungan di Persroan Terbatas. Selain itu pengaturan mengenai CSR ini juga termuat dalam Undang-Undang Nomor 25 Tahun 2007 tentang Penanaman Modal.

Sedangkan dalam hukum islam berdasarkan penelitian dan Nash-nash maupun hadits diketahui bahwasannya hukum syari'at islam mencakup diantaranya kemaslahatan manusia dimana dalam hal ini pula kegiatan CSR ini dipandang sebagai kegiatan untuk kemaslahatan manusia. Allah SWT berfirman:

Artinya:

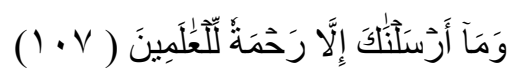

dan Tiadalah Kami mengutus kamu, melainkan untuk (menjadi) rahmat bagi semesta alam. (QS. Al-Anbiyaa': 107)

Melihat beberapa implementasi CSR yang dilakukan oleh beberapa perusahaan ini, jika dipandang dari segi hukum islam yakni dari tinjauan maslahah. Secara estimologis kata maslahah adalah searti dengan kata manfaat. ${ }^{21}$ Menurut Ibn Mandhur maslahah artinya setiap sesuatu yang mengandung manfaat baik dengan cara menarik seperti menarik hal-hal yang bersifat menguntungkan dan mengenakan atau dengan menolak atau menghindari seperti menolak atau menghindari hal-hal yang dapat merugikan dan menyakitkan. Secara terminologis syar'i maslahah dapat diartikan sebagai sebuah manfaat yang dikehendaki oleh Allah SWT untuk para hamba-Nya berupa pemeliharaan agama, jiwa akal, keturunan, harta benda dengan tinkat signifikasi yang berbeda satu sama lain. ${ }^{22}$

Sedangkan Maslahat Mursalah yaitu suatu kemaslahatan yang tidak disingggung oleh syara' dan tidak pula terdapat dalil-dalil yang menyuruh untuk mengerjakan atau meninggalkannya, sedangkan jika dikerjakan akan mendatangkan kebaikan yang besar atau kemaslahatan. Maslahat mursalah disebut juga maslahat yang mutlak. Karena tidak ada dalil yang mengakui kesahan atau kebatalannya. Dalam hal ini imam al-Ghazali mengatakan bahwa maslahan pada dasarnya ialah meraih manfaat dan menolak madharat. ${ }^{23}$ Jadi pembentuk hukum dengan cara maslahat mursalah semata-mata untuk mewujudkan kemaslahatan manusia dengan arti untuk mendatangkan manfaat dan menolak kemudharatan dan kerusakan bagi manusia. ${ }^{24}$

Penerapan maslahah ini sebagai sumber sumberhukum tidaklah bersifat mulak. Menurut madzhab Maliki terdapat beberapa syarat yang harus dipenuhi, antaralain: ${ }^{25}$

a. Maslahah itu harus sejalan dengan tujuan pokok syari'at islam dalam rangka mewujudkan kemaslahatan manusia. Dengan adanya persyaratan ini, berarti maslahah tidak boleh menegasikan sumber dalil yang lain, atau bertentangan dengan dalil yang qot'iy, akan tetapi harus sesuai dengan maslahat-maslahat yang ingin diwujudkan oleh syar'i. ${ }^{26}$

b. Maslahah itu secara substantif harus logis, yakni dapat diterima oleh akal sehat. Sehinga dimana diajukan kepada kelompo rasionalis akan dapat diterima.

c. Penerapan maslahah sebagai sumber hukum harus dapat menjamin kepentingan manusia yang bersifat primer (dharuri) ${ }^{27}$, atau mencegah timbulnya kerugian dan kesulitan.

\footnotetext{
${ }^{21}$ A. Malthuf Siroz, Paradigma Ushul Fiqh Negosiasi Konflik Antara Maslahah dan Nash. (Pustaka Ilmu. Yogyakarta: 2013), hlm. 11.

${ }^{22}$ Ibid... hlm. 12

${ }^{23}$ Ahmad Abdul Majid, Ushul Fiqih. (Garoeda Buana Indah. Pasuruan: 1994), hlm. 88-89.

${ }^{24}$ Kamal Muctar, dkk. Ushul Fiqh Jilid I. (Dana Bakti Wakaf. Yogyakarta: 1995), hlm. 143.

25 A. Malthuf Siroz, Paradigma Ushul Fiqh... op cit... hlm. 18.

${ }^{26}$ Muhammad Abu Zahrah. Ushul Figh, (Pustaka Firdaus. Jakarta: 1994), hlm. 427.

27 "tingkatan-tingkatan kemaslahatan masusia terdapat tiga tingkatan yakni (1). Tingkat dharuri yakni tingkatan yang harus ada yang mencakup lima tingkatan lagi yakni memelihara agama, jiwa, akal, keturunan
} 
Disamping itu para ulama Ushul Fiqh membuat kriteria-kriteria yang harus dipenuhi dalam mengaplikasikan maslahah, antara lain sebagai berikut: ${ }^{28}$

a. Maslahah tersebut harus termasuk dalam mu'amalah, sehingga kepentingan yang ada di dalamnya dapat dipertimbangkan secara rasional dan sama sekali tidak berkaitan dengan bidang ibadah.

b. Maslahah itu harus sejalan dengan jiwa syari'ah dan tidak bertentangan salah satu dari sumber-sumbernya.

c. Maslahah tersebut harus termasuk dalam kepentingan dharuriyyah ${ }^{29}$ dan hajiyyah ${ }^{30}$, bukan takmiliyah. ${ }^{31}$

CSR merupakan suatuhukum yang tidak ada dalil dan Nash yang mengharusakan dan melarang tentang kegiatan yang dilakukan oleh perusahaan. Jika hal tersebut dikaitkan dengan maslahah mursalah maka kegiatan tersebut penulis melihat adanya suatu hal yang bila dilakukan menimbulkan manfaaat yang besar bagi masyarakat dan perusahaan itu sendiri. Terlihat dari manfaat yang ditimbulkan, bahkan bagi masyarakat kecil hal tersebut sangatlah penting. Melihat masyarakat yang kekurangan biaya untuk membiayai anaknya untuk sekolah, tapi dengan ada sebuah perusashaanyang mengeluarkan CSRnya dibidang pendidikan untuk masyarakat sekitar. Maka disinilah terlihat bentuk kegiatan CSR ini yang bermanfaat bagi semua kalangan.

Banyak perusahaan yang melakukan tanggungjawab sosial perusahaannya dari berbagai bidang di antaranya: ${ }^{.2}$

1. Bidang pendidikan, dalam bidang ini diharapkan dapat memberikan suatu jalan menuju kesuksesan baik dari sudut pandang sosial maupun ekonomi. Dalam perusahaan memberikan dana berupa beasiswa kepada masyarakat yang kurang mampu dan berprestasi. selain berupa beasiswa dapat juga berupa pendidikan kesehatan seperti yang dilakukan oleh PT Unilever Indonesia, Tbk.

2. Bidang Kesehatan, bidang ini merupakan bidang yang peduli akan kesehatan dan kebersihan yang ada dalam lingkungan masyarakat, seperti halnya yang dilakukan oleh PT. International Nickel Indonesia Tbk., PT. Bakrie and Brother Tbk. yang memberikan pelayanan kesehatan dan pembinaan kesehatan serta pengembangan fasilitas kesehatan.

3. Bidang Ekonomi, dengan adanya kepedulian atau tanggung jawab dari perusahaan kepada masyarakatdari segi ekonomi, maka diharapkan dapat membangun dan membentuk ekonomi masyarakat setempat supaya dapat berkembang. Hal ini telah banyak dilakukan oleh berbagai perusahaan di Indonesia.

dan harta. (2). Tingkatan yang diperlukan (haji). (3). Tingkatan tahsini.” Lihat Kamal Muchtar Ushul Fiqh... hlm. 144.

28 A. Malthuf Siroz, Paradigma Ushul Fiqh.... op cit... hlm. 27-28

${ }^{29}$ Dharuriyyah yaitu maslahah yang harus diwujudkan demi tegaknya kehidupan di dunia maupun di akhirat nanti. Apabila tidak maka, kosekuensinya adalah rusak dan hancurnya tata kehidupan di dunia dan hilangnya kebahagiaan di akhirat, dan dapat diwujudkan dengan dua cara yakni aktif melakukan yang mendukung maslahah dan pasif meninggalkan yang dapat mengganggu maslahah tersebut. Lihat A. Malthuf Siroz, Paradigma Ushul Fiqh... hlm 30

${ }^{30}$ Hajiyyah yaitu maslahah yang dibutuhkan untuk tercapainya kebutuhn-kebutuhan da terhindarnya segala bentuk kepicikan dan kesulitan hidup. Konsekuensinya adalah timbulnya berupa kesulitan-kesulitan. Lihat A. Malthuf Siroz, Paradigma Ushul Fiqh... hlm 30

31 Tahsiniyyah yaitu maslahah yang berintikan penerimaan terhadap segala sesuatu yang baik dan menghindari segala sesuatu yang jelek yang ditolak oleh akal sehat. Lihat A. Malthuf Siroz, Paradigma Ushul Fiqh... hlm 31

${ }^{32}$ Mukti Fajar, "Tanggung Jawab Sosial Perusahaan di Indonesia Studi tentang Penerapan Ketentuan CSR pasa Perusahaan Mulitinasional, Swasta Nasional dan BUMN di Indonesia.” (Yogyakarta: Pustaka Pelajar. 2010), hlm. 332-373 
4. Bidang Lingkungan, hal ini diharapkan dapat memberikan suatu bentuk kepedulian terhadap lingkungan dan sumber daya alam, sehingga ekosistem dan yang lainnya dapat terjaga dan terlestarikan.

5. Bidang Sosial, sebagaimana bidang yang lain, bidang sosial ini mencakup berbagai aspek yang luas, seperti tanggung jawab untuk turut serta memajukan kegiatan penduduk pada semua jenjang, mendorong dan mendukung terselenggaranya kegiatan penduduk nonformal, mendorong kreatifitas masyarakat dibidang seni dan budaya. Di samping itu merupakan suatu hal yang diharapkan pihak perusahan dapat memberikan kepedulian bagi masyarakat setempat. Untuk menciptakan kesejahteraan bagi masyarakat setempat.

Ketika hal ini dikaitkan dengan negara dan islam yakni bahwasannya islam menegaskan kedudukan khalifah kaum muslimin sebagai ra'm (pengembala) yang bertanggung jawab atas ra'iyah (gembala)nya. Sehingga apabila gembalaannya ada yang sakit, kelaparan, terjadi kegaduhan, atau gembalanya ada yang mendzalimi oleh pengembala lain dan begitu seterusnya, maka semuanya merupakan tanggung jawab pengembala (khalifah/pemimpin) yang kesemuanya wajib ia selesaikan dengan baik. ${ }^{33}$ Sehingga ketika sebuah perusahaan yang tidak menerapkan nilai dan norma dapat dikatakan sebagai pelanggaran.

Hazairin dala pidato guru besarnya menyatakan bahwa Negara republik Indonesia adalah sebuah negara yang berdiri atas keinsyafan bahwa hukum dan kesusilaan (moral) tidak dapat dippisahkan. Hukum tanpa kesusilaan adalah kedzaliman. Sedangkan moral tanpa hukum adalah anarki dan utop yang dapat menjurus kepada perikebinatangan. Hanya hukum yang dipeluk oleh kesusilaan atau moral yang berakar kepada kesusilaan dapat mendirikan perikemanusiaan. Keinsyafan persenyawaan antara hukum dan kesusilaan termuat dalam UUD 1945 dalam Pasal 29 ayat 1 "Negara berdasarkan atas Ketuhanan Yang Maha Esa" ayat ini mengandung arti bahwa negara, bangsa dan masyarakat mematuhi norma-norma ilahi, yang meliputi norma hukum dan norma kesusilaan. ${ }^{34}$

Melihat kepada implementasi CSR yang dilakukan oleh perusahaan seperti penelitian yang telah dilakukan oleh Mukti Faza, yakni CSR dibidang Pendidikan, ketika mencoba melihat dari dasar hukum baik dari hukum positif ataupun hukum islam kegiatan ini sejalan dengan apa ang telah menjadi suatu kewajiban yang dilakukan oleh sebuah perusahaan dan sesuat dengan peraturan perundang-undangan yang berlaku di Indonesia. Jika dalam hukum islam kegiatan yang dilakukan di bidang Pendidikan ini merupakan suatu hal yang dikatakan sebagai perbuatan ibadah. Melihat bahwasannya mendidikan dalam pandangan islam merupakan suatu hal yang sangat penting.

Pada konteks ini mencari sebuah ilmu merupakan suatu hal yang diwajibkan bagi setiap umat muslim. Dalam hal ini ilmu yang dicari baik ilmu agama maupun ilmu yang lainnya. Sehingga ilmu tersebut menjadi suatu hal yang sangat penting dalm kehidupan umat manusia. Hal ini disebabkan setip hal dalam melakukan sesuatu tentunya memerlukan suatu ilu untuk memahami, mempelajari dan menggunakan hal tersebut. Maka tidak heran Allah SWT memberikan tingkatan yang berbeda bagi orang-orang yang berilmu seperti dalam firman-Nya:

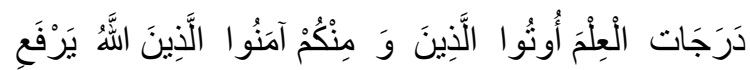

Artinya: "Niscaya Allah akan meninggikan orang-orang yang beriman di antaramu dan orang-orang yang diberi ilmu pengetahuan beberapa derajat. dan Allah Maha mengetahui apa yang kamu kerjakan." (QS. Al-Mujaadilah: 11)

\footnotetext{
${ }^{33}$ M. Sholahuddin, Asas-Asas Ekonomi Islam, (Rajawali Press. Jakarta: 2007), hlm 284.

${ }^{34}$ Muhammad Daud Ali, Hukum Islam, (Rajawali Press. Jakara: 2013), hlm 149-150.
} 
Pada ayat tersebut Allah memposisikan orang-orang yang berilmu memberikan perbedaan dengan orang-orang yang tidak mempunyai ilmu. Sehingga dalam konteks pelaksanaan CSR dibidang pendidikan ini meupakan suatu hal yang sangat baik. Melihat keadaan masyarakat indonesia yang mayoritas tidak mampu dibidang ekonomi. Dengan keadaan pemerintah ang belum mampu menjangkau terhadap semua elemen masyarakat Dindonesia ini untuk memberikan kesejahteraan. Maka dengan adanya kegiatan CSR di bidang ini merupakan suatu hal yang arif, ketika melihat dari maslahah mursalah nya, pendidikan merupaka suatu kepentingan yang rimer bagi kehidupan manusia, dan jika hal tersebut tidak dilakukan maka akan terjadi suatu ketimpangan di bidang pendidikan.

Disamping itu CSR juga telah membantu negara dalam bentuk mengentaskan dari buta huruf. Selain itu telah ikut serta dalam melaksanakan titah Undang-undang Dasar Negara Republik Indonesia tahun 1945 yakni mencerdaskan kehidupan bangsa.

Selanjutnya, kegiatan CSR yang dilakukan dibidang kesehatan. Kegiatan ini jika dilihat dari hukum islam memberikan suatu pelayanan kesehatan merupakan suatu hal yang wajib pula, kegiatan CSR ini merupakan suatu kegiatan yang dianjurkan, sehingga hal tersebut menimbulkan suatu manfa'at bagi masyarakat banyak. Dengan adanya kegiatan CSR di bidang kesehatan ini suatu hal yang memberikan suatu akses kepada masyarakat dalam mendapatkan hak-haknya, yakni hak untuk hidup sehat. Ketika negara berum bisa menjamah atau belum bisa tembus kepada semua kalangan yang ada di masyarakat, maka disini peran swasta memberikan pernanya.

Sedangkan kegiatan CSR yang dilakukan dalam bidang lingkungan ini merupakan suatu kegiatan yang baik, baik ditinjau dari segi etik, agama, budaya dan hukum nasional. Hal ini diperlukan suatu kesadaran yang begitu besar terhadap kepedulian ini, dikarenakan kerusakan lingkungan ini kebanyakan diakibatkan atau disebankan oleh manusia itu sendiri, baik itu atas nama inividual maupun kelompok. Bahwasannya Allah SWT berfirman:

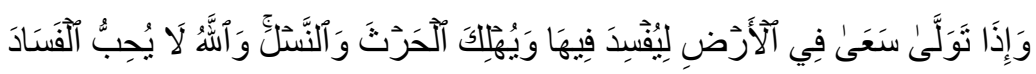

Artinya:

".Dan apabila ia berpaling (dari kamu). ia berjalan di bumi untuk Mengadakan kerusakan padanya, dan merusak tanam-tanaman dan binatang ternak, dan Allah tidak menyukai kebinasaan. " (Al-Baqoroh:205)

Melihat ayat tersebut bahwasannya Allah telah menegaskan bahwa semua kerusakan dimuka bumi ini, baik itu lingkungan, hewan hal tersebut dilakukan oleh manusia, baik secara individu maupun secara kelompok. Allah SWT berfirman:

Artinya:

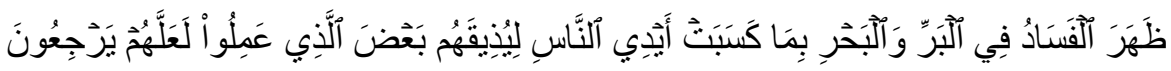

"telah nampak kerusakan di darat dan di laut disebabkan karena perbuatan tangan manusia, supaya Allah merasakan kepada mereka sebahagian dari (akibat) perbuatan mereka, agar mereka kembali (ke jalan yang benar) “. (QS. Ar-Rum;41)

Pada ayat tersebut dengan jelas bahwasannya setiap kerusakan yang ditimbulkan di muka bumi ini ilah perbuatan manusia itu sendiri. Dan terkadang manusia tersebut dalam melakukan kerusakan mereka mengaku tidak sadar, Allah SWT berfirman:

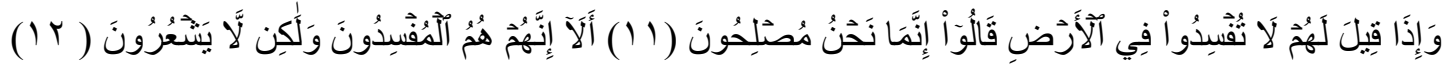


Artinya:

"dan bila dikatakan kepada mereka:"Janganlah kamu membuat kerusakan di muka bumi". mereka menjawab: "Sesungguhnya Kami orang-orang yang Mengadakan perbaikan." 12. Ingatlah, Sesungguhnya mereka Itulah orang-orang yang membuat kerusakan, tetapi mereka tidak sadar. " (QS. Al-Baqoroh: 11-12)

Dengan demikian kegiatan yang dilakukan oleh sebuah perusahaan yakni dengan CSR dibidang lingkungan, merupakan suatu kegiatan yang arif dan bijaksana. Baik dalam rangka melestarikan lingkungan yang telah rusak akibat perbuatan manusia itu sendiri, baik secara individu maupun kelompok.

Kegiatan-kegiatan CSR ini penulis berkesimpulan bahwasnnya jika dipandang atau dilihat dari maslahah mursalah ialah suatu kegiatan yang baik dan penting. Baik bagi kehidupan masyarakat itu sendiri maupun bagi kearipan lokal lingkungan masyarakat tersebut.

\section{Penutup}

\section{Simpulan}

Setelah melakukan pembahasan mengenai CSR (Corporate Social Rsponsibility) dalam prospektif maslahah mursalah ini bahwaasannya definisi mengenai CSR sendiri menurut UU yang berlaku di indonesia ini ialah komitmen Perseroan untuk berperan serta dalam pembangunan ekonomi berkelanjutan guna meningkatkan kualitas kehidupan dan lingkungan yang bermanfaat, baik bagi Perseroan sendiri, komunitas setempat, maupun masyarakat pada umumnya. Sedangkan maslahah mursalah sendiri memiliki definisi yaitu suatu kemaslahatan yang tidak disingggung oleh syara' dan tidak pula terdapat dalil-dalil yang menyuruh untuk mengerjakan atau meninggalkannya, sedangkan jika dikerjakan akan mendatangkan kebaikan yang besar atau kemaslahatan. Maslahat mursalah disebut juga maslahat yang mutlak.

Sedangkan implementasi dari CSR di tinjau dari prospektif maslahah mursalah ialah sangat bersesuaain dengan apa yang dimaksud dengan maslahah mursalah dimana kegiatan-kegiatan yang dilakukan oleh sebuah perusahaan. Hal ini disebabkan oleh kegiatan yang dilakukan merupakan kegiatan yang bersifat sosial dan kemanusiaan. Disamping itu kegiatan yang dilakukan banyak yang beringgungan dengan pelestarian lingkungan sosial. Sehingga hal tersebut termasuk kepada salah satu prinsip dari maslahah mursalah yakni lebih kepada pemenuhan kebutuhan primer manusia.

\section{Saran}

Adapun yang menjadi saran dari pembahasan dalam artikel ini ialah sebagai berikut:

a. Bagi perusahaan, ialah dapat melaksanakan kegiatan CSRnya lebih kepada mementingkan kepentingan masyarakat. Baik dalam memenuhi kebutuhan masyarakat dalam hal ini pendidikan, ekonomi dan kesehatan, maupun di lingkungan dalam hal ini ialah pelestarian lingkungan, penananman pohon dan lain sebagainya.

b. Bagi masyarakat, dalam hal ini peran masyarakat diperlukan dalam selalu berperan aktif dalam setiap kegiatan yang dilakukan oleh perusahaan. Diasamping itu peran masyarakat juga berperan dalam menjaga dan mengelola lingkungan sekitar.

c. Bagi pemerintah sendiri ialah dengan memberikan pengawasan terhadap kegiatan yang dilakukan oleh perusahaan, sehingga dapat memberikan ketenangan dan kenyamanan bagi masyarakat, maka tujuan dari negara tersebut dapat tercapai dan terpenuhi. 


\section{Daftar Pustaka}

A. Malthuf Siroz, Paradigma Ushul Fiqh Negosiasi Konflik Antara Maslahah dan Nash. Pustaka Ilmu. Yogyakarta: 2013

Amir Mahmud, Bank Syari'ah Teori, Kebijakan dan Studi Empiris di Indonesia, Erlangga. Jakarta: 2010

Depatemen Agama. Al-Qur'an dan Terjemahan. Jakarta: 2011

Wahbah Al-Zuhayly, Zakat Kajian Berbagai Mazhab, Remaja Rosdakarya. Bandung: 2008 Ahmad Abdul Majid, Ushul Fiqih. Garoeda Buana Indah. Pasuruan: 1994

Faisal Badroen, dkk, Etika bisnis dalam Islam, Kencana Prenada Media. Jakarta: 2006

Hartono Ahmad Jaiz, Aliran dan Paham Sesat di indonesia, Pustaka Al-Kausar. Jakarta: 2002

Ismail Muhammad Syah, dkk. Filsafat Hukum Islam, (Bumi Aksara. Jakarta: 1999

Joko Prastowo dan Miftahul huda, Corporate Social Responsibility Kunci Meraih Kemuliaan Bisnis. Samudra Biru. Yogyakarta: 2011

Kamal Muctar, dkk. Ushul Fiqh Jilid I. Dana Bakti Wakaf. Yogyakarta: 1995

Konsideran Menimbang UU PT

M. Umer Capra dan Habib Ahmed, diterjemahkan oleh Ikhwan Abidin Asri, Corporate governance Lembaga Keuangan Syari'ah, Bumi Aksara. Jakarta: 2008

Mohammad Daud Ali, Sistem Ekonomi Islam Zakat dan Wakaf, UI Press. Jakarta: 1988

Muhammad Abu Zahrah. Ushul Fiqh, Pustaka Firdaus. Jakarta: 1994

Muhammad Bagir Al-Habsyi, Fiqih Praktis Menurut Al-Qur'an, Asunnah, Pendapat Para Ulama, Mizan. Bandung: 1999

Muhammad Daud Ali, Hukum Islam, Rajawali Press. Jakara: 2013

Muhammad, Aspek Hukum dalam Mu'amalat, Graha Ilmu. Yogyakarta: 2007

Mukti Fajar, "Tanggung Jawab Sosial Perusahaan di Indonesia Studi tentang Penerapan Ketentuan CSR pasa Perusahaan Mulitinasional, Swasta Nasional dan BUMN di Indonesia." Yogyakarta: Pustaka Pelajar. 2010

Undang-Undang Dasar Negara Republik Indonesia 1945

Sholahuddin, Asas-Asas Ekonomi Islam, Rajawali Press. Jakarta: 2007

Undang-Undang Nomor 40 Tahun 2007 tentang Perseroan Terbatas 